\title{
STAKEHOLDER MAP IN THE CULTURAL PROJECT MANAGEMENT PROCESS ON THE EXAMPLE OF ST. DOMINIC'S FAIR
}

\author{
MARIUSZ CHMIElEWSKI, ${ }^{1}$ RenATA PŁOSKA, ${ }^{2}$ JOANNA PróCHNIAK ${ }^{3}$
}

University of Gdańsk, Faculty of Management, POLAND

1 e-mail: mapich@wp.pl

2 e-mail: renata.ploska@ug.edu.pl

${ }^{3}$ e-mail: joanna.prochniak@ug.edu.pl

\begin{abstract}
RECEIVED
10 December 2018

ACCEPTED

28 December 2018

JEL

CLASSIFICATION

Z10

KEYWORDS cultural project, stakeholders, stakeholder map

ABSTRACT This article is an attempt to use one of the tools used in project management, which is stakeholder analysis, for the preparation of St. Dominic's Fair. One of the elements of this analysis, called stakeholder mapping, was used in the article. As a result, it was possible to identify stakeholders of key importance for good organization of the fair, including, among others, the MTG SA, the authorities of Gdańsk, exhibitors and organizers of accompanying events
\end{abstract}

\section{Introduction}

Trade and cultural events, such as markets and fairs, have accompanied people from the earliest times, although they have now taken on a slightly different character. These used to be cyclical events whose main purpose was to facilitate trade (Środa-Murawska et al., 2015, p. 126). Today, these are tourist products, often organized or initiated by local governments or entities associated with local governments, which are part of cultural tourism and 
whose main task is, above all, to attract tourists. The complex nature of fairs nowadays requires good management. It seems that the project approach, which provides a number of tools for planning and implementing such a cyclical event well, including managing relations with the stakeholders, is particularly useful in this case.

The main objective of the study was to assess the significance and character of the identified stakeholders as well as their relations with a local government project such as St. Dominic's Fair in Gdańsk. The study focused on two stakeholder maps based on two-dimensional matrices. The assessment of individual stakeholders' positions was made using the expert method of brainstorming. During the analysis, source data made available by the MTG SA (Gdańsk International Fair Co.) was used.

\section{Cultural project stakeholders}

The concept of a project, in practical terms, is presented in the light of project methodologies. According to Project Management Institute (PMI), a project is a temporary endeavor undertaken to create a unique product, service, or result (A Guide..., 2017, pp. 4-5). On the other hand, according to International Project Management Association (IPMA), a project is a time and cost constrained operation to realize a set of defined deliverables (the scope to fulfil the project's objectives), up to quality standards and requirements (IPMA, 2018). The Office of Government Commerce (OGC) definition assumes that a project is a temporary organization that is created for the purpose of delivering unique defined deliverables or results in a given period of time and with the use of defined resources (What..., 2018). The ISO 10006:2017 standard defines a project as: a process, consisting of a set of coordinated activities with precisely defined start and end dates; it is a process aimed at achieving an objective within defined time, cost and resource constraints (ISO 10006:2003.., 2018).

There are various, characteristic features of projects. One of them is a specific objective, characteristic for each project, defined as a basic parameter. Achievement of the objective is possible thanks to the creation of end products assigned to a given project. Another characteristic feature of each project is its uniqueness, understood as its certain difference in relation to other projects. Next, project is an activity that takes place within a specific time frame - each project has its own specific start and end, which means that its implementation is associated with a certain temporariness. Individual projects are both implemented and created by specially appointed teams. This feature is largely due to the diversity of projects - since each project is different, different teams will be needed to implement them, equipped with different resources necessary during the course of activities. A consequence of this is high interdisciplinarity of activities undertaken during the project implementation each time. The abovementioned project features influence another characteristic feature that can describe each such undertaking - this is risk. Risk means both threats and opportunities that may arise during the project implementation. A characteristic feature of each project is the fact that its implementation often does not take place in a separate environment, but takes place in an environment that has the potential to influence the changes occurring during its implementation (Nicholas, Steyn, 2015, pp. 27-30).

Organizations increasingly use projects as a tool for achieving success, which results in a parallel implementation of the entire project portfolio within one organization. Individual projects are connected with one another in a specific way, if only due to the fact that they are implemented by one entity. Apart from institutional links within the project portfolio, other types of connections can be distinguished, i.e. time or financial. Managing a project 
portfolio in an organization means allocating resources between projects in such a way as to achieve the company's objectives (Brzozowski, 2014, p. 72).

Projects are implemented both in economic and public practice, as well as in the case of other activities carried out by people, e.g. in the field of culture. By cultural projects, we mean activities characterized by the presented features, whose objectives are related to the area of culture.

Undoubtedly, effective implementation of various projects is possible thanks to the use of a number of tools proposed within the framework of individual project management methodologies - one of such tools is project stakeholder analysis.

The different stages of the project's impact value chain involve different stakeholders. The problem of stakeholders is so wide that, despite many attempts to define and group them, there are still many discrepancies.

The vast majority of stakeholder theories concern the organization level, the prism of projects is only occasionally included. Based on a literature review, the most common and universal definition by R.E. Freeman (1984, p. 53), considered to be the main promoter of stakeholder theory, dates back to 1984 . The author originally promoted stakeholders as individuals or groups that influence or are influenced by the organization under analysis. Later, R.E. Freeman proposed modifications to his original approach. His definitions have gained a lot of popularity, which does not mean widespread public acceptance precisely because of the focus on the aspects related to the construction of the organization (Jepsen, Eskerod, 2009, pp. 335-343; Mitchell, Agle, 1997, pp. 854-886). Examples of definitions of stakeholders at the project level are presented in Table 1.

Table 1. Selected definitions of stakeholders at the project level

\begin{tabular}{|c|c|}
\hline Author (year) & Project stakeholder definitions \\
\hline Cleland (1986) & Individuals and institutions that share a stake or an interest in the project \\
\hline Turner (1999) & People or groups whose lives or environment is affected by the project but who receive no direct benefit from it \\
\hline McElroy, Mills (2003) & $\begin{array}{l}\text { Person or group of people who have a vested interest in the success of a project and the environment within which the } \\
\text { project operates }\end{array}$ \\
\hline Bourne, Walker (2005) & $\begin{array}{l}\text { Individuals or groups who have an interest or some aspect of rights or ownership in the project and can be impacted } \\
\text { by the project }\end{array}$ \\
\hline Walker et al. (2008) & $\begin{array}{l}\text { Individuals or groups who have an interest or some aspect of rights in the project, and can contribute to, or be impacted } \\
\text { by, either the work or the outcomes of the project }\end{array}$ \\
\hline Ward, Chapman (2008) & Various parties who may affect the form, progress and outcomes of a project \\
\hline PMI (2008) & $\begin{array}{l}\text { Individuals and organizations that are actively involved in the project or whose interests may be affected as result } \\
\text { of project execution or project completion }\end{array}$ \\
\hline
\end{tabular}

Source: Aaltonen (2010).

However, it is more important to identify stakeholders' attitude towards the project than to define them, because only then we can manage their attitudes and respond to their actions. Examples of classifications of attitudes and impact of stakeholders on a project based on the literature are presented in Table 2. 
Table 2. Examples of attitudes and impact of project stakeholders

\begin{tabular}{ll}
\hline \multicolumn{1}{c}{ Author (year) } & \multicolumn{1}{c}{ Attitude and impact of project stakeholders } \\
\hline \multirow{2}{*}{ Goodpaster (1991) } & Fiduciary \\
& Non-fiduciary \\
\hline \multirow{2}{*}{ Clarkson (1995) } & Direct impact \\
& Indirect impact \\
& Peripheral, secondary impact \\
\hline Blair et al. (1996) & Potential cooperation \\
\hline & Potential risk \\
\hline Mitchell et al. (1997); Driscoll, Starik (2004) & Power \\
& Urgency \\
& Legitimacy \\
\hline \multirow{2}{*}{ Trocki, Sońta-Drączkowska (2009) } & Proximity \\
& Consubstantial \\
& Contractual \\
\hline
\end{tabular}

Source: own literature review.

Analyzing the reports of various organizations on the subject of culture, the following universal groups of stakeholders in cultural projects can be distinguished:

1. Originators (culture and art animators, institutions and organizations working in culture).

2. Decision - makers (public institutions at local, regional, and national level).

3. Politicians.

4. Implementers and contractors (people involved in the technical and organizational sphere of the project).

5. Institutions supporting cultural projects and culture at the national and international level.

6. Financing institutions (e.g. banks, cultural foundations, public institutions).

7. Consumers of cultural goods and services (recipients, customers, audience et.).

The identification of stakeholders, their classification and attributed impact enable stakeholder management, which in turn determines successful implementation of a cultural project.

\section{Methodology}

Managing relations with project stakeholders consists of several phases, started by the activities related to the widely-understood stakeholder analysis (Trocki, Sońta-Drączkowska, 2009, p. 371; A Guide to..., 2017, pp. 1618). This analysis is not an easy one, mainly due to the large number and diversity of the surveyed subjects and relations, as well as due to its qualitative nature.

The first step in stakeholder analysis is their identification. Next, each identified interest group must then be subjected to a detailed and multi-criteria analysis. The results of the analysis of individual stakeholders are multidimensional characteristics, which then enable the stakeholder evaluation. This evaluation allows to determine the significance of each stakeholder for the success of the project, their attitude towards the project and possible behaviors (Trocki, Sońta-Drączkowska, 2004, pp. 369-381). In this phase of the works, the stakeholder maps are applied.

Various approaches to stakeholder mapping can be found in the literature. For the purpose of the study authors decided to concentrate on the approach based on the use of different types of two-dimensional matrices. 
In this approach, placing a specific stakeholder on such a map means they are classified into one of the categories proposed in a given model, which is the starting point for the project or organization managers to decide whether to adopt an appropriate action strategy (Łada, Kozarkiewicz, 2010, pp. 23-28; Johnson, Scholes, Whittington, 2008, pp. 181-184). Out of various proposals for such maps, two were selected for the purpose of this study.

The first proposal is a tool enabling the assessment and classification of stakeholders on the basis of their potential for threatening the venture and the potential for cooperation. The matrix constructed on the basis of such criteria included four categories of stakeholders (Savage, Nix, Whitehead, Blair, 1991, pp. 65-67):

1. Entities with a high potential for cooperation, but at the same time capable of posing a real threat (mixed blessing), for whom collaboration is recommended.

2. Entities with a high potential for cooperation and a low potential for threat (supportive stakeholders), who should be involved as widely as possible in the activities undertaken.

3. Entities to whom the defense strategy should be applied, due to their high potential for threat and low possibility to support the organization's activities (non-supportive stakeholders).

4. Stakeholders of minor importance (marginal stakeholders) who do not constitute any significant support or threat and should be limited to having their actions monitored.

The second map is a proposal for the classification of stakeholders according to their level of interest in a given project and their ability to influence its course. Close cooperation is recommended for interest groups with a high interest in and significant impact on the project, referred to as key or leading players. In the case of stakeholders who may exert a significant impact on the course of the project, but do not show much interest in the project, the organization's efforts should focus on ensuring their satisfaction. Interested stakeholders who are not in a position to exert a significant impact on the project require mainly information activities, while those with no significant impact and showing little commitment require minimal effort that in principle consists solely of monitoring (Johnson, Scholes, Whittington, 2008, pp. 156-157).

The popularity of stakeholder maps results from the fact that they allow a simplified, synthetic, and at the same time pictorial way to present the conclusions drawn from often very detailed and extensive descriptions of particular groups. Thus, they are a tool supporting the decision-making process related to the selection of appropriate action strategies. It should be remembered, however, that their usefulness depends on the extent to which they reflect the actual state of relations with stakeholders, and as the latter are dynamic in nature, stakeholder maps should be periodically reviewed and updated.

\section{Stakeholder maps of St. Dominic's Faip}

Every year in Gdańsk, on the last Saturday in July, begins, lasting 23 days and considered the largest in Poland and one of the largest open-air commercial and cultural events in Europe, St. Dominic's Fair. The origins of this event date back to 1260 . For centuries, the fair was a great attraction, even at a time when the importance of this type of events began to decline. After 1989, this event became a tourist product, building the tourist attractiveness of Gdańsk and the whole region. In recent years, the fair has become a huge event, where for three weeks visitors can get acquainted with the rich offer presented at nearly a thousand stalls and trade stands (Tu brzmi..., 2018).

Such a large undertaking requires good preparation, including good stakeholder identification. At St. Dominic's Fair, there are many interest groups representing different areas of social and economic life. A list of the most important identified stakeholders of this project is presented in Table 3. 
Table 3. Stakeholders of St. Dominic's Fair

\begin{tabular}{cl}
\hline Symbol & \\
\hline A & Gdańsk International Fair Co. (MTG SA) - the main organizer of the event \\
B & City of Gdańsk - the originator of the event and the site administrator \\
C & Authorities of Pomeranian Voivodeship \\
D & Gdańsk Tourist Organization and other such entities \\
E & Exhibitors (craftsmen, traders, artists, etc.) \\
F & Organizers of accompanying events (concerts, exhibitions, etc.) \\
G & Local catering companies \\
H & Local accommodation services \\
I & Local shops \\
J & Suppliers of the services and goods for the needs of the entities participating in the fair \\
K & Local cultural institutions \\
L & Sponsors \\
M & Residents of Tricity visiting the fair \\
N & Tourists \\
O & Inhabitants of the center of Gdańsk \\
P & Companies and institutions not directly related to the fair, located in the center of Gdańsk \\
Q & Local transport companies \\
R & Domestic/foreign transport companies (airlines, railways, etc.) \\
S & Financial sector companies \\
T & Inspection bodies \\
U & Security services (police, health service, etc.) \\
W & Municipal cleaning services \\
V & Media (traditional and electronic) \\
X & Non-governmental organizations \\
Y & Dominicans - former organizers of the fair \\
Z & Other cities with competitive tourist offers \\
\hline & \\
\hline &
\end{tabular}

Source: own elaboration based on research.

The first stakeholder map allowed for assessment of potential stakeholder behavior, taking into account their tendencies and potential for cooperation for the fair, as well as potential threat they may pose, thus hindering its efficient implementation (Figure 1).

The general conclusion arising from the analysis of the above matrix is that in the case of the analyzed project, entities with a relatively high potential for cooperation dominate among the stakeholders, with a large part of them classified as supportive stakeholders. However, there is also quite a large group of entities that can be described as a „mixed blessing”, i.e. as stakeholders who, under certain circumstances, may become a threat to the project implementation. Such stakeholders require special attention, including: security services, companies responsible for maintaining order, inspection bodies, and the media.

The second map allowed to group stakeholders on the basis of their level of interest in the project itself, its course and effects (both positive and negative), as well as their impact on the project (Figure 2). 


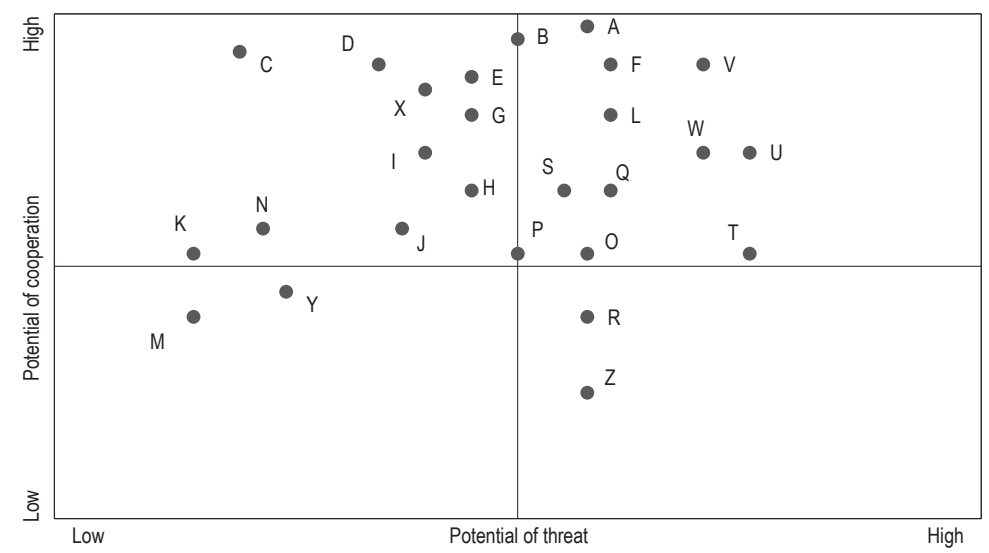

Figure 1. A map of St. Dominic's Fair stakeholders (potential for cooperation/potential for threat)

Source: own elaboration based on research.

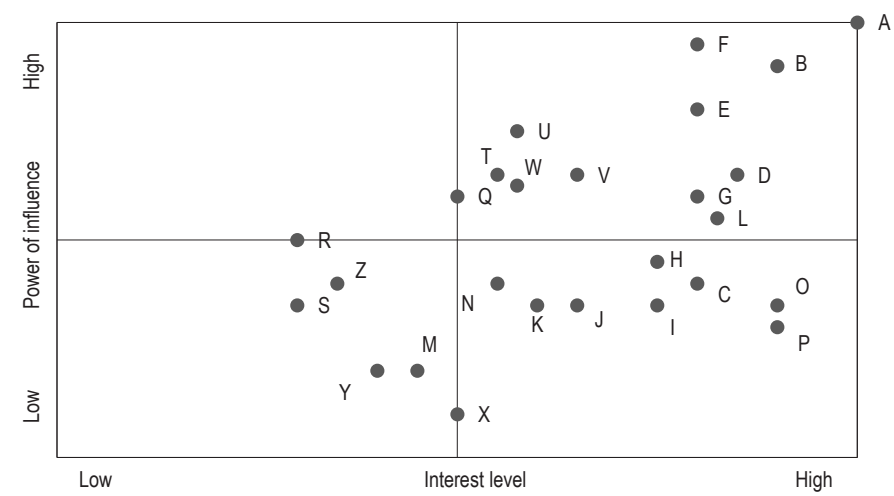

Figure 2. A map of St. Dominic's Fair stakeholders (level of interest/power of influence)

Source: own elaboration on the basis of research.

The analysis of the map allows us to conclude that the fair's stakeholders are definitely dominated by those who are interested in the event and its course. This means that good communication will play an important role in managing relations with these groups. This will be particularly important in the case of the "key players" who include, among others: MTG SA (along with their employees), the authorities of Gdańsk, exhibitors and organizers of accompanying events.

On the basis of a comparison of the results of the analyses presented on both maps, it is possible to create a list of particularly significant stakeholders. These include: the entity responsible for coordinating the entire project 
(MTG SA), the City of Gdańsk, organizers of various cultural events which increase the attractiveness of the event, sponsors, inspection bodies, local services responsible for order, transport and security, and the media.

The conclusions drawn from the presented stakeholder maps do not, of course, give a full picture of the analyzed entities and their relations with them. Nevertheless, they make an important contribution to the process of managing a complex and multidimensional undertaking that is St. Dominic's Fair. An important element of this process is the development and implementation of appropriate strategies for dealing with individual stakeholders, and the overall view that such instruments give certainly facilitates decision-making when planning subsequent editions of this project. The analysis may be the basis for the risk management process of the analyzed cultural project.

\section{Conclusions}

Contemporary cultural projects, including fairs, can be described as complex undertakings requiring skillful management. Their success is influenced, among other things, by good management of relations with often very diverse interest groups. These groups can influence the implementation of this type of project to varying degrees and in different ways, which means that they can be seen as support or a potential source of risk.

In this study, we have used stakeholder map - a tool which is helpful in the process of managing complex cultural projects, such as St. Dominic's Fair, which allows the assessment of potential impact of specific interest groups on the project. Their application allowed, among other things, to identify those stakeholders who, due to their potential, willingness to cooperate, or interest in the project should be of particular interest.

The work on stakeholder maps of St. Dominic's Fair led to the conclusion that the general analysis of project stakeholders, a fragment of which is presented in this study, should be complemented by a similar analysis carried out for individual events making up the event known as the fair. Individual events included in the analyzed cultural event can be treated as separate projects. It appears, therefore, that managing such a project is, in fact, managing the whole portfolio of smaller and larger projects. In the case of such an approach, the links between individual projects forming St. Dominic's Fair should be taken into account. To sum it up, it can be stated that stakeholder analysis is a tool facilitating implementation of a cultural project in accordance with the planned objectives.

\section{References}

A Guide to the Project Management Body of Knowledge (2017). USA: PMI, pp. 4-5, 16-18.

Aaltonen, K. (2010). Stakeholder Management in International Projects. Doctoral Dissertation Series 2010/13, Aalto University, Espoo.

Blair, J.D., Fottler, M.D., Whitehead, C.J. (1996). Diagnosing the stakeholder bottom line for medical group practices. Key stakeholders' potential to threaten and/or cooperate. Medical Group Management Journal, 43 (2), pp. 42-51.

Brzozowski, M. (2014). Metody zarządzania portfelem projektów. Studia Oeconomica Posnaniensia, 2 (11), 72.

Clarkson, M.E. (1995). A Stakeholder Framework for Analyzing and Evaluating Corporate Social Performance. Academy of Management Review,20(1), 92-117.

Driscoll, C., Starik, M. (2004). The Primordial Stakeholder: Advancing the Conceptual Consideration of Stakeholder Status for the Natural Environment. Journal of Business Ethics, 49 (1), 55-73.

Freeman, R.E. (1984). Strategic Management. A Stakeholder Approach. Boston: Pitman.

Goodpaster, K.E. (1991). Business Ethics and Stakeholder Analysis. Business Ethics Quarterly, 1 (1), 53-73.

IPMA (2018). NCB National Competence Baseline. Polskie Wytyczne Kompetencji IPMA, wersja 3.0. Stowarzyszenie Project Management Polska. Retrieved from: www.ipma.pl/sites/default/files/certyfikacja/NCB_v3_PL.pdf. 
ISO 10006:2003. Quality management systems - Guidelines for quality management in projects (2018). Retrieved from: www.iso.org/ standard/36643.html.

Jepsen, A.L., Eskerod, P. (2009). Stakeholder analysis in projects: Challenges in using current guidelines in the real world. International Journal of Project Management, 27, 335-343.

Johnson, G., Scholes, K., Whittington, R. (2008). Exploring corporate strategy. New York: Prentice Hall.

Łada, M., Kozarkiewicz, A. (eds.) (2010). Zarządzanie wartością projektów. Instrumenty rachunkowości zarządczej i controllingu. Warszawa: C.H. Beck.

Mitchell, R.K., Agle, B.R., Wood, D.J. (1997).Toward a Theory of Stakeholder Identification and Salience: Defining the Principle of Who and What Really Counts. The Academy of Management Review, 22 (4), 853-886.

Nicholas, J.M., Steyn, H. (2015).Zarządzanie projektami - zastosowanie w biznesie, inżynierii i nowoczesnych technologiach. Warszawa: Oficyna Wolter Kluwer business.

Savage, G.T., Nix, T.W., Whitehead, C.J., Blair, J.D. (1991).Strategies for assessing and managing organizational stakeholders. Academy of Management Executive, 5 (2), 61-65.

Środa-Murawska, S., Rogatka, K., Grzelak-Kostulska, E., Biegańska, J., Kosmela, M. (2015). Czy tylko blaszane zegarki? Znaczenie współczesnych jarmarków - przykład Jarmarku Katarzyńskiego w Toruniu. Zeszyty Naukowe Uniwersytetu Szczecińskiego,853, Ekonomiczne Problemy Turystyki, 30 (2), 125-141.

Trocki, M., Sońta-Drączkowska, E. (eds.). (2009). Strategiczne zarządzanie projektami. Warszawa: Bizarre.

Tu brzmi historia o jarmarku (2018). Retrieved from: www.jarmarkdominika.pl/tu-brzmi-historia-o-jarmarku.

What is PRINCE2 (2018). Retrieved from: www.prince2.com/eur/what-is-prince2.

Cite this article aS: Chmielewski, M., Płoska, R., Próchniak J. (2018). Stakeholder map in the cultural project management process on the example of St. Dominic's Fair. European Journal of Service Management, 4 (28/2), 87-95. DOI: 10.18276/ejsm.2018.28/2-10. 